\title{
Identification of Pup1 QTL linked DNA marker haplotypes for molecular breeding of phosphorous deficiency tolerant rice varieties
}

\author{
Y.C. Aluwihare ${ }^{1,2}$, M.D.M. Chamikara ${ }^{1}$, D.R.R.P. Dissanayake ${ }^{1}$, S.I. Karunarathne ${ }^{1}$, G.K.S. Ananda ${ }^{1}$, \\ S.K. Kannangara ${ }^{1}$, O.V.S. Madhukalpani ${ }^{1}$, D.N. Sirisena ${ }^{3}$, W.L.G. Samarasinghe ${ }^{3}$ and S.D.S.S. \\ Sooriyapathirana ${ }^{1,2^{*}}$ \\ ${ }^{I}$ Department of Molecular Biology and Biotechnology, Faculty of Science, University of Peradeniya, Peradeniya. \\ ${ }^{2}$ Postgraduate Institute of Science, University of Peradeniya, Peradeniya. \\ ${ }^{3}$ Rice Research and Development Institute, Bathalagoda, Ibbagamuwa.
}

\begin{abstract}
The development of phosphorous deficiency (PD) tolerant cultivars is important for rice farming. The DNA markers linked to Pup1, the major quantitative trait locus (QTL) for PD tolerance, have been developed using reference rice cultivars Kasalath and Nipponbare, however these markers cannot be directly employed in regional breeding programmes as specific cultivars that are important to a region/country may contain diverse QTL haplotypes complicating marker assisted breeding (MAB). Thus identification of the Pupl linked DNA marker haplotypes present in local cultivars is the prerequisite for MAB of PD tolerance in rice. Therefore, the objective of this study was to identify the Pupl haplotypes from a panel of 30 rice cultivars important for breeding programmes in Sri Lanka. A total of 17 Pupl linked DNA markers were used to genotype the rice cultivars previously characterised for PD tolerance in comparison to Kasalath and Nipponbare. Overall 28 Pup 1 haplotypes were identified in the marker allele based clustergram and the Pupl hapoltype in Kasalath was observed in four PD tolerant cultivars Sudubalawee, Bw 364, Kaluheenati and Marss. However, the PD tolerant cultivars Bg 94-1, Bg 403, H-7, H-4 and Murungakayan contain haplotypes that are clustered separately from Kasalath indicating the possibility of conferring PD tolerance in the absence of Kasalath haplotype. The marker-trait association analysis for the PD tolerance revealed that selection of the favourable alleles such as $433 \mathrm{bp}$ allele of $K 46-K 2$ marker could increase PD tolerance by 0.73 .
\end{abstract}

The detected positively associated alleles with PD tolerance can be readily employed in MAB of rice in Sri Lanka.

Keywords: Marker assisted breeding of rice, phosphorous uptake, rice breeding in Sri Lanka, rice landraces.

\section{INTRODUCTION}

Phosphorous $(\mathrm{P})$ is the most problematic macronutrient in fertiliser management of rice farming because it forms complexes with $\mathrm{Fe}^{3+}$ and $\mathrm{Al}^{3+}$ ions and becomes unavailable to the plants (Bieleski, 1973; Holford \& Mattingly, 1976; Shen et al., 2011). Application of artificial $P$ fertiliser is very expensive and can significantly contribute to environmental pollution (Reddy et al., 1999; Cordell et al., 2009; Bennett et al., 2001). Therefore, the current situation of $\mathrm{P}$ fertiliser management in rice farming is at a critical state, thus sustainable, fast acting solutions such as marker assisted breeding (MAB) of $\mathrm{P}$ deficiency $(\mathrm{PD})$ tolerant rice varieties are required. $\mathrm{MAB}$ (i.e. molecular breeding) is one of the most powerful and the least controversial biotechnological tools available for genetic improvement of plants and animals (Beuzen et al., 2000; Collard \& Mackill, 2008; Moose \& Mumm, 2008). QTL mapping, validation and establishment

\footnotetext{
*Corresponding author (sunethss09@gmail.com; (DD https://orcid.org/0000-0002-5592-1742)
} 
of linked marker haplotypes or alleles, systematically designed breeding programmes and deployment of DNA testing to check the defined haplotypes are the key steps in molecular breeding (Ribaut \& Hoisington, 1998; Collard et al., 2005).

In order to layout an efficient MAB programme towards PD tolerance, the underlying genetics must be unravelled as the first step. Genetics of PD tolerance in rice has been a central research focus in rice science since 1998 (Ni et al., 1998; Wissuwa et al., 1998). A major quantitative trait locus (QTL), Pup1, has been identified (Wissuwa et al., 1998; Wissuwa \& Ae, 2001), validated (Chin et al., 2011), fine mapped (Wissuwa et al., 2002; Heuer et al., 2009) and characterised for the genes present within the region using the reference rice cultivars Kasalath and Nipponbare (Heuer et al., 2009; Chin et al., 2010; 2011). Kasalath contains the entire Pupl locus and exhibits PD tolerance whereas Nipponbare has a $130 \mathrm{~kb}$ deletion within Pup1 locus and exhibits PD sensitivity. Pupl has attracted much attention from the rice breeders because of its higher effect $(80 \%)$ on the overall variability of PD tolerance (Wissuwa et al., 2002). A set of DNA markers linked to Pup1 locus have been developed based on the sequence polymorphisms of underlying genes. These markers could be used to introgress the favourable haplotypes of Pup1 QTL into important rice varieties that are sensitive to PD (Chin et al., 2011).

Rice breeding programmes are specific to countries and diverse geographical locations because of the requirement of diverse breeding objectives and the utilisation of varied genetic material as the breeding parents. The QTLs detected in one location cannot be directly utilised in MAB of another region because the QTLs are environment dependent. Therefore, the flanking DNA markers of a QTL in published studies cannot be directly employed in country or location specific breeding programmes without validation. Therefore, the Pupl linked DNA markers published in many studies using Kasalath and Nipponbare cannot be directly recruited to a specific MAB programme in a country. PCR amplification of the DNA markers and detection of their allelic states, understanding informative polymorphisms and establishment of marker-allele haplotypes for the entire Pup1 QTL are essential groundwork before implementing them in MAB (Aluwihare et al., 2016a). The validation of published QTLs in this manner is essential before adapting them as tools in breeding programmes (Mengistu et al., 2012; Yan et al., 2014; Zhang et al., 2014).
Application of MAB for rice in Sri Lanka is still at its infancy. Recently a set of rice landraces and improved varieties that represent the breeding pool and panel of mega production varieties in Sri Lanka were characterised for PD tolerance and they were grouped into three PD tolerant levels, namely tolerant, moderately tolerant and sensitive (Aluwihare et al., 2016b). The objective of the present study was to identify the Pupl linked markerallele haplotypes of the rice landraces and improved varieties characterised for PD tolerance by Aluwihare et al. (2016b) to facilitate the MAB programmes to produce PD tolerant rice varieties for Sri Lanka.

\section{METHODOLOGY}

\section{Rice cultivars and PD tolerance}

A set of rice genotypes containing 12 landraces, three old improved (released before 1970) and 15 newly improved (released after 1970) varieties (herein after collectively referred to as cultivars) that are predominantly used in Sri Lankan rice breeding and production were assessed in the present study (Table 1). Seeds from authenticated stocks available at the Rice Research and Development Institute (RRDI), Bathalagoda, Sri Lanka were taken as the planting material. PD tolerance of these 30 rice genotypes were assessed in Yala and Maha seasons in 2012 and published in Aluwihare et al. (2016b). The same dataset was used in the present study to find the association of the PD traits with DNA marker-alleles linked to Pupl QTL.

\section{Detection of DNA marker polymorphism}

Immature leaf samples were collected from each cultivar and subjected to DNA isolation using Dnaeasy ${ }^{\circledR}$ plant mini kit (Qiagen, Solna, Sweden). Genomic DNA samples of Kasalath and Nipponbare were also included as the standards for PCR. matK, a universal plant DNA barcoding primer pair (Hollingsworth et al., 2011), was used to substantiate the quality and aptness of DNA for PCR amplification. DNA samples were amplified using markers developed for the Pup1 QTL region (Table 2) (Heuer et al., 2009; Chin et al., 2010; 2011; PariascaTanaka et al., 2014). The PCR conditions were provided using a Thermal Cycler (Takara, Otsu Shiga, Japan) as follows; initial denaturation at $94{ }^{\circ} \mathrm{C}$ for $5 \mathrm{~min}$, then 35 cycles of $94^{\circ} \mathrm{C}$ for $30 \mathrm{~s}$, primer annealing temperature (Ta) (Table 2) for $90 \mathrm{~s}$, and $72{ }^{\circ} \mathrm{C}$ for $2 \mathrm{~min}$, final extension at $72{ }^{\circ} \mathrm{C}$ for $10 \mathrm{~min}$. The amplified PCR products were size separated using $1.5 \%$ ethidium bromide stained agarose gel electrophoresis. 
Table 1: Rice cultivars characterised for Pupl linked DNA marker haplotypes

\begin{tabular}{|c|c|c|c|c|c|}
\hline $\begin{array}{l}\text { PD tolerance } \\
\text { score }^{\mathrm{a}}\end{array}$ & $\begin{array}{l}\text { Name of the } \\
\text { cultivar }^{\mathrm{b}}\end{array}$ & $\begin{array}{c}\text { Released } \\
\text { year }\end{array}$ & Parental cultivars & $\begin{array}{l}\text { Maturity } \\
\text { class } \\
\text { (months) }\end{array}$ & $\begin{array}{l}\text { Mean yield } \\
(\mathrm{mt} / \mathrm{ha})^{\mathrm{c}}\end{array}$ \\
\hline \multirow[t]{4}{*}{1} & At 306 & 2004 & OB 2273 / At 05 & 3.0 & 3.80 \\
\hline & At 354 & 1992 & Bg 94-1 / Pokkali & 3.5 & 5.00 \\
\hline & $\operatorname{Bg} 357^{d}$ & 1997 & Bg 797 / Bg 300 // 85-1580 / Senerang M-17 & 3.5 & 6.70 \\
\hline & $\operatorname{Bg} 300^{\mathrm{d}}$ & 1987 & Bg 367-7 // IR 841/Bg 276-5 & 3.0 & 6.00 \\
\hline \multirow[t]{14}{*}{2} & Suwandel & - & - & 4.0 & 2.75 \\
\hline & Suduheenati & - & - & 4.0 & 2.75 \\
\hline & Hondarawala & - & - & 4.0 & 2.75 \\
\hline & Pokkali & - & - & 4.0 & 2.75 \\
\hline & Rathuheenati & - & - & 3.5 & 2.75 \\
\hline & Sudurusamba & - & - & 4.0 & 2.75 \\
\hline & At 353 & 1992 & Bg 94-1(R) / Bg 400-1 // Bg 94-1 & 3.5 & 4.00 \\
\hline & $\operatorname{Bg} 250$ & 2005 & Farmer field selection & 2.5 & 4.00 \\
\hline & $\mathrm{Bg} 358^{\mathrm{d}}$ & 1999 & Bg 12-1 / Bg 1492 & 3.5 & 6.00 \\
\hline & $\operatorname{Bg} 450^{\mathrm{d}}$ & 1985 & $\operatorname{Bg} 12-1 * 2 / \operatorname{IR} 42$ & $4.0-4.5$ & 5.00 \\
\hline & $\operatorname{Bg} 352^{\mathrm{d}}$ & 1992 & $\mathrm{Bg} 380$ / Bg 367-4 & 3.5 & 6.80 \\
\hline & Bg 379-2 & 1980 & Bg 96-3*2/ Ptb 33 & $4.0-4.5$ & 6.00 \\
\hline & Bw 364 & 2006 & IR 36 / Bw 267-3-11M & 3.5 & 4.00 \\
\hline & $\operatorname{Ld} 356$ & 1994 & Bw 451 / Bw 351 & 3.5 & 4.30 \\
\hline \multirow[t]{12}{*}{3} & Murungakayan & - & - & 4.0 & 4.00 \\
\hline & Sudubalawee & - & - & 4.0 & 2.50 \\
\hline & Marss $^{e}$ & $1950^{\mathrm{f}}$ & - & 4.5 & 2.75 \\
\hline & Kokuwellai & - & - & 4.0 & 2.75 \\
\hline & Kaluheenati & - & - & 3.5 & 2.75 \\
\hline & Rathel & - & - & 5.0 & 2.75 \\
\hline & $\mathrm{H}-10$ & 1968 & $\mathrm{PP} /$ Marss // H-5 & 3.0 & 3.00 \\
\hline & $\mathrm{H}-4$ & 1958 & Murungakayan / Marss & $4.0-4.5$ & 4.50 \\
\hline & $\mathrm{H}-7$ & 1964 & PP / Marss // H-5 & 3.5 & 3.50 \\
\hline & At $362^{\mathrm{d}}$ & 2002 & At $85-2$ / Bg 380 & 3.5 & 7.00 \\
\hline & $\mathrm{Bg} 403$ & 1993 & $83-1026$ / Bg 379-2 & $4.0-4.5$ & 4.00 \\
\hline & $\mathrm{Bg} 94-1^{\mathrm{d}}$ & 1975 & IR 262 / Ld 66 & 3.5 & 6.00 \\
\hline
\end{tabular}

a PD tolerance scores are indicated as described in Aluwihare et al. (2016b). 1: Sensitive; 2: Moderately tolerant; 3: Tolerant ${ }^{\mathrm{b}}$ Standard rice variety names as given in the Database of Rice Varieties, Department of Agriculture, Sri Lanka (2006).

${ }^{\mathrm{c}}$ The yield data available at RRDI, Sri Lanka.

${ }^{\mathrm{d}}$ Mega rice varieties grown in Sri Lanka.

${ }^{\mathrm{e}}$ Marss is also known as Mas.

${ }^{\mathrm{f}}$ Marss was introduced to Sri Lanka in 1950.

The symbol '-' indicates the unavailability of information for landraces. 
Table 2: The details of the Pup1 linked DNA markers used to detect haplotypes

\begin{tabular}{|c|c|c|c|c|}
\hline Marker $^{\mathrm{x}}$ & Forward and reverse primer sequences $\left(5^{\prime} \rightarrow 3^{\prime}\right)$ & Band sizes $^{y}(b p)$ & $\mathrm{Ta}\left({ }^{\circ} \mathrm{C}\right)$ & Reference \\
\hline$R M 28073$ & $\begin{array}{l}\text { GTGTTGGTGGTGATGAAGCAAGG } \\
\text { GGACGAAGGATGTATGTGTCTGTACC }\end{array}$ & 656 & 55 & \\
\hline$K 20$ & $\begin{array}{l}\text { TCAGGTGATGGGAATCATTG } \\
\text { TGTTCCAACCAAACAACCTG }\end{array}$ & 240,243 & 55 & \\
\hline K29 & $\begin{array}{l}\text { CCATAGTAGCACAAGAAACCGACA } \\
\text { GCTTCAATGAGCCCAGATTACGAA }\end{array}$ & 491 & 55 & Chin et al., 2010 \\
\hline$K 41$ & $\begin{array}{l}\text { TGATGAATCCATAGGACAGCGT } \\
\text { TCAGGTGGTGCTTCGTTGGTA }\end{array}$ & 382 & 57 & \\
\hline K42 & $\begin{array}{l}\text { CCCGAGAGTTCATCAGAAGGA } \\
\text { AGTGAGTGGCGTTTGCGAT }\end{array}$ & 918 & 57 & \\
\hline K43 & $\begin{array}{l}\text { AGGAGGATGAGCCTGAAGAGA } \\
\text { TCGCACTAACAGCAGCAGATT }\end{array}$ & 912 & 57 & \\
\hline K46 & $\begin{array}{l}\text { TGAGATAGCCGTCAAGATGCT } \\
\text { AAGGACCACCATTCCATAGC }\end{array}$ & 523 & 57 & \\
\hline$K 46-K 1$ & $\begin{array}{l}\text { TGAGATAGCCGTCAAGATGCT } \\
\text { TGAGCCAGTAGAATGTTTTGAGG }\end{array}$ & 342 & 57 & \\
\hline$K 46-K 2$ & $\begin{array}{l}\text { CTGAAGTGAAAAGAATGACTAA } \\
\text { TGAGCCAGTAGAATGTTTTGAGG }\end{array}$ & 433 & 57 & Pariasca-Tanaka et al., 2014 \\
\hline$K 46-3$ & $\begin{array}{l}\text { TCCAAAGATCTCTGATTTTGGC } \\
\text { GCTTTCCAACATCTCAAGGACT }\end{array}$ & 400 & 57 & \\
\hline$K 46-C G 1$ & $\begin{array}{l}\text { CTAGAGTATCTCCACAGTCGTT } \\
\text { AAGGACCACCATTCCATAGC }\end{array}$ & 258 & 57 & \\
\hline K46-CG2 & $\begin{array}{l}\text { CCGAAGTAAGAAGAATGACGGA } \\
\text { TGATCCAGGAGAATGTTTTGTGG }\end{array}$ & 433 & 57 & \\
\hline K48 & $\begin{array}{l}\text { CAGCATTCAGCAAGACAACAG } \\
\text { ATCCGTGTGGAGCAACTCATC }\end{array}$ & 847 & 57 & \\
\hline K52 & $\begin{array}{l}\text { ACCGTTCCCAACAGATTCCAT } \\
\text { CCCGTAATAGCAACAACCCAA }\end{array}$ & 505 & 57 & Chin et al., 2010 \\
\hline K59 & $\begin{array}{l}\text { GGACACGGATTCAAGGAGGA } \\
\text { TGCTTTCCATTTGCGGCTC }\end{array}$ & 550 & 57 & \\
\hline Ba76H14_7154 & $\begin{array}{l}\text { GAAACGGGGTCAAATAAGC } \\
\text { GGGTTCGTCCAACAGGAGTA }\end{array}$ & 292,259 & 55 & Heuer et al., 2009 \\
\hline$R M 28102$ & $\begin{array}{l}\text { CACTAATTCTTCGGCTCCACTTTAGG } \\
\text { GTGGAAGCTCCGAGAAAGTGC }\end{array}$ & 168 & 55 & Chin et al., 2010 \\
\hline
\end{tabular}

${ }^{\mathrm{x}}$ Markers are listed according to their order in the Kasalath genome.

${ }^{\mathrm{y}}$ Band sizes are reported in the references indicated.

\section{Data analysis}

\section{DNA marker polymorphism and cluster analysis}

The presence or absence of each marker allele was detected by the presence/absence of the PCR fragments on agarose gel and was recorded for each cultivar. Marker polymorphism of each marker was calculated based on gene diversity (GD) using GDdom Software (Abuzayed et al., 2016). GDdom employs the following formula to calculate GD.
$\mathrm{GD}_{i}=2 f_{i}\left(1-f_{i}\right)$

Roldan - Ruiz et al., (2000)
$\mathrm{GD}_{\mathrm{i}}=$ gene diversity of marker ' $\mathrm{i}$ ', $f_{\mathrm{i}}=$ frequency of the amplified allele (band presence), and 1- $f_{\mathrm{i}}=$ frequency of the null allele (band absence)

Based on the binary data of DNA marker polymorphism, the dissimilarity matrix was calculated using unweighted pair group method with arithmetic means (UPGMA) (Nei \& Kumar, 2000) in Phylip Package version 3.697 (Felsenstein, 2005) and the tree 
was visualised in FigTree v1.4.3. (Rambaut, 2018). The tree was edited by adding labels for the rice cultivars, their PD tolerance levels and the cluster labels. The cluster position and the PD tolerance score of each cultivar were subjected to a chi-square test using the statistical package Minitab 17 (Minitab Inc., 2010) to detect the association between clustering and PD tolerance scores.

\section{Marker-trait association analysis}

The marker-allele haplotypes were identified and drawn as a clustergram, graphically presented and the polymorphic allelic data were subjected to association analysis with the traits for PD tolerance, plant height (PIH), number of tillers (NT), shoot dry weight (SDW), shoot $\mathrm{P}$ concentration (SPC), shoot $\mathrm{P}$ uptake (SPU), $\mathrm{P}$ utilisation efficiency (PUE) and overall PD tolerance score using general lineal model (GLM) procedure in TASSEL 5.0 software (Bradbury et al., 2007).

\section{RESULTS AND DISCUSSION}

\section{Marker polymorphism}

The expected monomorphic band was detected for DNA of all the cultivars in matK based PCR revealing the good quality of the extracted DNA samples. All the
Pup1 DNA markers provided clear polymorphic bands in PCR for the studied set of cultivars. A total of 23 alleles were detected for all 17 markers. Out of these, 14 markers accounted for 18 of the polymorphic alleles. The markers K20, Ba76H14_7154 and RM28102 were monomorphic for the 32 cultivars. However, they could be used as candidate loci to detect any possible variations within the sequence tagged sites (STS) present among different cultivars (Aluwihare et al., 2017). The highest GD (0.50) was detected for $K 46, K 46-K 1, K 48$ and $K 59$ (Table 3). A total of five novel bands were detected for Sri Lankan (SL) cultivars (not present in either Kasalath or Nipponbare) in the markers K29, K46-K2, K46$C G 2$ and $K 52$ indicating potentially specific or unique Pup1 QTL haplotypes and hence unique PD tolerance mechanisms in these cultivars (Table 3 ).

\section{Cluster analysis}

The UPGMA clustergram yielded 11 main clusters $(\mathrm{C} 1$ - C11). The $\mathrm{C} 1$ contained 12 rice cultivars including the standard PD tolerant cultivar, Kasalath. These 12 cultivars contained eight PD tolerant, three moderately PD tolerant and one PD sensitive genotypes (Table 1). Within C1, five cultivars were identified as $100 \%$ similar to Kasalath Pup1 and they were labelled as "Sub C Kasalath". Except Bw 364 (a moderately PD tolerant cultivar), all the others in Sub C Kasalath were PD

Table 3: The polymorphism of the Pupl linked DNA markers in studied rice cultivars

\begin{tabular}{|c|c|c|c|c|}
\hline Marker & $\begin{array}{c}\text { No. of alleles } \\
\text { detected }\end{array}$ & No. of polymorphic alleles & $\begin{array}{l}\text { No. of novel bands } \\
\text { (present only in SL cultivars) }\end{array}$ & Average GD \\
\hline$R M 28073$ & 1 & 1 & 0 & 0.30 \\
\hline K20 & 1 & 0 & 0 & 0.00 \\
\hline$K 29$ & 2 & 2 & 1 & 0.19 \\
\hline$K 41$ & 1 & 1 & 0 & 0.43 \\
\hline$K 42$ & 1 & 1 & 0 & 0.06 \\
\hline K43 & 1 & 1 & 0 & 0.47 \\
\hline$K 46$ & 1 & 1 & 0 & 0.50 \\
\hline K46-K1 & 1 & 1 & 0 & 0.50 \\
\hline$K 46-K 2$ & 2 & 2 & 1 & 0.46 \\
\hline$K 46-3$ & 2 & 1 & 0 & 0.12 \\
\hline$K 46-C G 1$ & 2 & 1 & 0 & 0.47 \\
\hline$K 46-C G 2$ & 2 & 2 & 2 & 0.34 \\
\hline$K 48$ & 1 & 1 & 0 & 0.50 \\
\hline K52 & 2 & 2 & 1 & 0.42 \\
\hline K59 & 1 & 1 & 0 & 0.50 \\
\hline Ba76H14_7154 & 1 & 0 & 0 & 0.00 \\
\hline$R M 28102$ & 1 & 0 & 0 & 0.00 \\
\hline
\end{tabular}


tolerant. Seven cultivars including Nipponbare were clustered individually. The cultivar Nipponbare was the most distant genotype. The clusters C6 and C8 contained the most frequently grown mega rice varieties (which are PD sensitive) in Sri Lanka. C7 contained seven moderately tolerant rice cultivars and one tolerant cultivar. The $\mathrm{C} 11$ is unique because it contains only PD tolerant Sri Lankan cultivars / landraces that are genetically distant from Sub C Kasalath (Figure 1).
The existence of separate C11 to Sub C Kasalath implies the occurrence of unique PD tolerant mechanisms in Sri Lankan rice germplasm. Aluwihare et al. (2017) also confirms the existence of this group by studying the sequence polymorphism within K20 locus of Pup1. The association between cluster positions (Figure 1) and PD tolerance scores (Table 1) was found to be significant at $p<0.01$. This indicates significant association of the groups (clusters) with the response to P starvation.

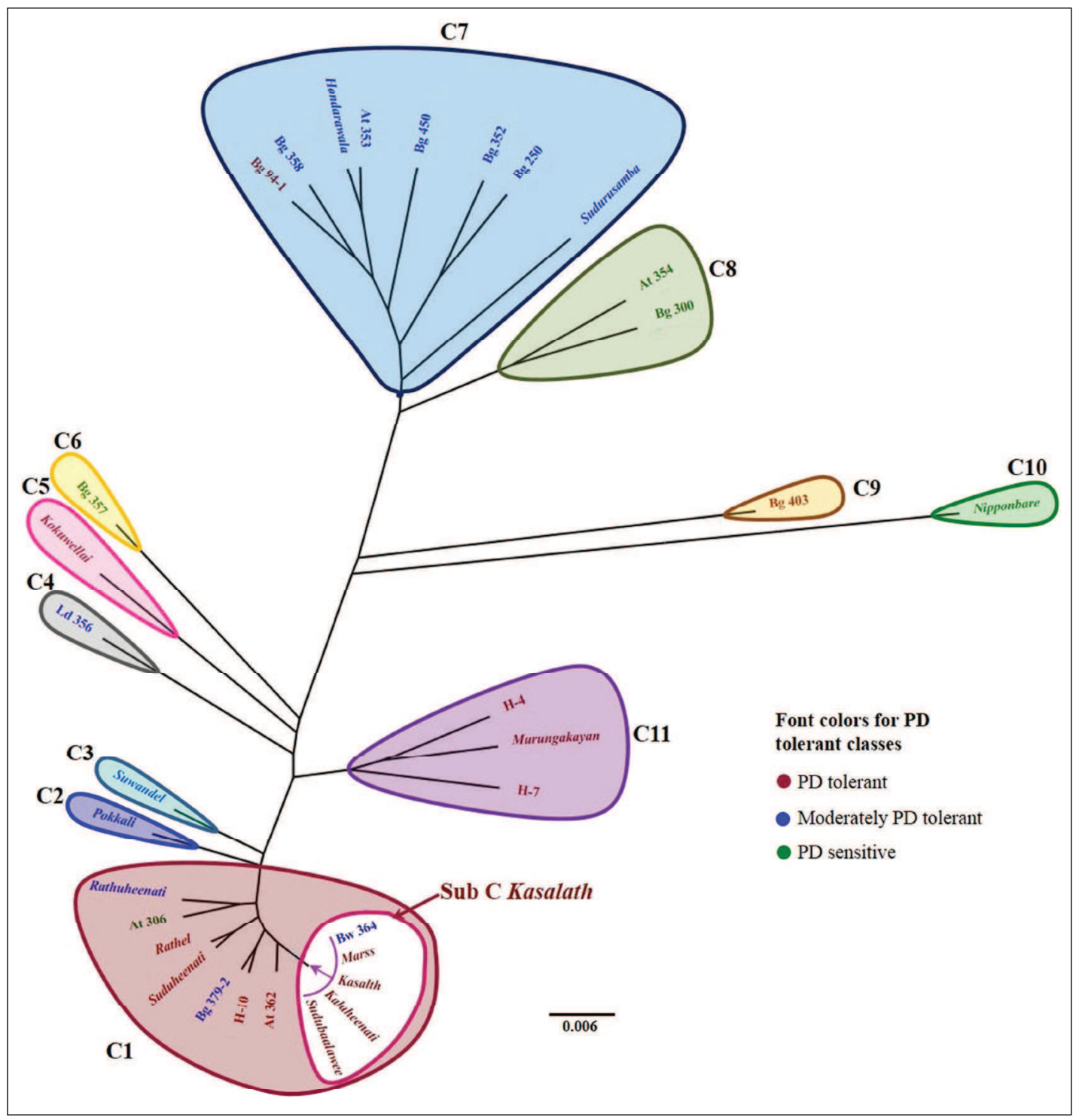

Figure 1: The cluster diagram constructed for 32 rice cultivars based on the Pupl linked DNA marker polymorphism. The dissimilarity matrix was obtained using unweighted pair group method with arithmetic means (UPGMA) in Phylip Package version 3.697 (Felsenstein, 2005) and the tree was visualised in FigTree v1.4.3. (Rambaut, 2018). The cluster (C) and other labels were separately added to the FigTree output. 
Table 4: Association between polymorphic marker alleles and PD tolerance traits of the rice cultivars

\begin{tabular}{|c|c|c|c|c|c|c|c|}
\hline \multirow[t]{2}{*}{ Marker } & \multirow[t]{2}{*}{ Allele (bp) } & \multirow[t]{2}{*}{ Trait } & \multirow[t]{2}{*}{ Growing condition } & \multicolumn{2}{|c|}{ Mean trait value } & \multirow[t]{2}{*}{ Gain of selection } & \multirow[t]{2}{*}{$\mathrm{P}$ value } \\
\hline & & & & $\begin{array}{c}\text { When allele } \\
\text { present }\end{array}$ & $\begin{array}{c}\text { When allele } \\
\text { absent }\end{array}$ & & \\
\hline \multirow[t]{2}{*}{$R M 28073$} & 656 & $\mathrm{PlH}$ & Maha $-\mathrm{P}_{30}-\mathrm{GH}$ & 79.25 & 64.78 & 14.47 & 0.0115 \\
\hline & 850 & NT & Maha- $\mathrm{P}_{0}-\mathrm{F}$ & 3.00 & 2.21 & 0.79 & 0.0457 \\
\hline \multirow{4}{*}{$K 29$} & 850 & NT & Yala $-\mathrm{P}_{0}-\mathrm{F}$ & 3.20 & 2.28 & 0.92 & 0.0040 \\
\hline & 850 & NT & Yala- $\mathrm{P}_{30}-\mathrm{GH}$ & 6.44 & 3.99 & 2.45 & 0.0206 \\
\hline & 491 & NT & Yala $-\mathrm{P}_{0}-\mathrm{F}$ & 2.25 & 2.88 & -0.63 & 0.0130 \\
\hline & 382 & $\mathrm{PlH}$ & Maha- $\mathrm{P}_{0}-\mathrm{GH}$ & 77.6 & 65.21 & 12.39 & 0.0461 \\
\hline \multirow[t]{2}{*}{$K 41$} & 382 & PUE & Maha- $\mathrm{P}_{30}-\mathrm{GH}$ & 1.25 & 1.55 & -0.30 & 0.0400 \\
\hline & 382 & SPU & Maha- $\mathrm{P}_{0}-\mathrm{GH}$ & 11.40 & 7.73 & 3.67 & 0.0033 \\
\hline$K 43$ & 912 & SPU & Yala- $\mathrm{P}_{30}-\mathrm{GH}$ & 18.01 & 13.87 & 4.14 & 0.0122 \\
\hline \multirow{7}{*}{ K46 } & 523 & PUE & Maha- $\mathrm{P}_{30}-\mathrm{GH}$ & 1.16 & 1.48 & -0.32 & 0.0122 \\
\hline & 523 & NT & Yala- $\mathrm{P}_{0}-\mathrm{GH}$ & 3.38 & 4.73 & -1.35 & 0.0094 \\
\hline & 433 & $\mathrm{PlH}$ & Maha- $\mathrm{P}_{0}-\mathrm{GH}$ & 81.25 & 62.82 & 18.43 & 0.0007 \\
\hline & 433 & $\mathrm{PlH}$ & Maha- $\mathrm{P}_{30}-\mathrm{GH}$ & 81.63 & 68.43 & 13.2 & 0.0031 \\
\hline & 433 & SDW & Maha- $\mathrm{P}_{0}-\mathrm{GH}$ & 18.36 & 13.26 & 5.10 & 0.0086 \\
\hline & 433 & SPU & Maha- $\mathrm{P}_{0}-\mathrm{GH}$ & 11.26 & 8.85 & 2.41 & 0.0390 \\
\hline & 433 & PDT Score & Maha $-\mathrm{P}_{0}-\mathrm{GH}$ & 2.57 & 1.84 & 0.73 & 0.0028 \\
\hline \multirow[t]{7}{*}{$K 46-K 2$} & 433 & $\mathrm{PlH}$ & Yala- $\mathrm{P}_{0}-\mathrm{GH}$ & 81.03 & 61.24 & 19.79 & 0.0416 \\
\hline & 433 & $\mathrm{PlH}$ & Yala $-\mathrm{P}_{30}-\mathrm{GH}$ & 72.81 & 54.25 & 18.56 & 0.0128 \\
\hline & 433 & SPU & Yala- $\mathrm{P}_{30}-\mathrm{GH}$ & 19.1 & 14.22 & 4.88 & 0.0405 \\
\hline & 110 & $\mathrm{PlH}$ & Maha- $\mathrm{P}_{0}-\mathrm{GH}$ & 63.51 & 79.1 & -15.59 & 0.0084 \\
\hline & 110 & $\mathrm{PlH}$ & Maha- $\mathrm{P}_{30}-\mathrm{GH}$ & 67.85 & 80.6 & -12.75 & 0.0070 \\
\hline & 110 & SPU & Yala- $\mathrm{P}_{30}-\mathrm{GH}$ & 12.95 & 19.13 & -6.18 & 0.0064 \\
\hline & 258 & PUE & Yala $-\mathrm{P}_{30}-\mathrm{GH}$ & 1.57 & 1.16 & 0.41 & 0.0356 \\
\hline \multirow[t]{5}{*}{$K 46-C G 1$} & 258 & SDW & Yala- $\mathrm{P}_{0}-\mathrm{GH}$ & 23.71 & 16.29 & 7.42 & 0.0330 \\
\hline & 258 & $\mathrm{SPC}$ & Yala- $\mathrm{P}_{30}-\mathrm{GH}$ & 0.67 & 0.88 & -0.21 & 0.0389 \\
\hline & 433 & NT & Yala $-\mathrm{P}_{0}-\mathrm{F}$ & 3.20 & 2.29 & 0.91 & 0.0040 \\
\hline & 433 & NT & Yala- $\mathrm{P}_{30}-\mathrm{GH}$ & 6.44 & 3.99 & 2.45 & 0.0206 \\
\hline & 130 & $\mathrm{PlH}$ & Maha- $\mathrm{P}_{0}-\mathrm{GH}$ & 64.68 & 80.02 & -15.34 & 0.0063 \\
\hline \multirow{5}{*}{$K 46-C G 2$} & 130 & SDW & Maha- $\mathrm{P}_{0}-\mathrm{GH}$ & 13.55 & 18.18 & -4.63 & 0.0182 \\
\hline & 130 & SPU & Maha- $\mathrm{P}_{0}-\mathrm{GH}$ & 8.82 & 11.28 & -2.46 & 0.0349 \\
\hline & 130 & PDT Score & Maha- $\mathrm{P}_{0}-\mathrm{GH}$ & 1.91 & 2.5 & -0.59 & 0.0225 \\
\hline & 130 & $\mathrm{PlH}$ & Yala- $\mathrm{P}_{30}-\mathrm{GH}$ & 51.75 & 71.58 & -19.83 & 0.0090 \\
\hline & 130 & SPU & Yala- $\mathrm{P}_{30}-\mathrm{GH}$ & 13.15 & 19.01 & -5.86 & 0.0118 \\
\hline \multirow[t]{2}{*}{$K 48$} & 847 & PUE & Maha- $\mathrm{P}_{30}-\mathrm{GH}$ & 1.16 & 1.55 & -0.39 & 0.0017 \\
\hline & 700 & NT & Maha- $\mathrm{P}_{0}-\mathrm{GH}$ & 1.78 & 1.36 & 0.42 & 0.0333 \\
\hline \multirow{3}{*}{ K52 } & 700 & PUE & Yala- $\mathrm{P}_{30}-\mathrm{GH}$ & 1.54 & 1.10 & 0.44 & 0.0245 \\
\hline & 700 & SPC & Yala- $\mathrm{P}_{30}-\mathrm{GH}$ & 0.68 & 0.91 & -0.23 & 0.0196 \\
\hline & 505 & SPU & Maha- $\mathrm{P}_{0}-\mathrm{GH}$ & 10.99 & 7.50 & 3.49 & 0.0179 \\
\hline \multirow{2}{*}{ K59 } & 550 & SPU & Maha- $\mathrm{P}_{0}-\mathrm{GH}$ & 11.55 & 9.04 & 2.51 & 0.0242 \\
\hline & 550 & $\mathrm{SPC}$ & Yala- $\mathrm{P}_{0}-\mathrm{F}$ & 19.93 & 25.47 & -5.54 & 0.0066 \\
\hline
\end{tabular}

Gain of selection is calculated by subtracting the mean trait value when allele is absent from the mean trait value when allele is present. $\mathrm{p}$ value indicates the probability level for significant mean differences calculated using Tassel 5.0 software. PlH: plant height (cm); NT: number of tillers; SDW: shoot dry weight (grams per pot); SPC: shoot P concentration [amount of P (mg) in 1 gram of dry shoot]; SPU: shoot P uptake (mg P per pot); PUE: P utilisation efficiency (biomass produced per unit $\mathrm{P}$ accumulated in shoot tissue); PDT: P deficiency tolerance score assigned in Aluwihare et al. (2016b). 


\section{Haplotype analysis}

When 23 alleles of the 17 markers were considered together for 32 cultivars, a total of 28 Pup 1 marker allele haplotypes were detected implying a huge genomic diversity within the Pup1 QTL region (Figure 1). The cultivars Kasalath, Sudubalawee, Bw 364, Kaluheenati and Marss shared the same haplotype (Figure 1) and all these five cultivars were PD tolerant (the score of 3 ) or moderately tolerant (the score of 2). Therefore, this particular haplotype can be readily employed in MAB for PD tolerance. The marker locus K46-CG2, which was developed for African rice (Pariasca-Tanaka et al., 2014), was missing in these five cultivars (C_Kasalath). A total of 16 Sri Lankan cultivars contained an allele for the marker K46-CG2 implying their genetic relatedness to African rice than Kasalath, Nipponbare and the rest of the Sri Lankan cultivars. Nipponbare exhibited a unique Pupl genomic haplotype with entire INDEL region missing as observed by Chin et al. (2010). However, the variable loci of this INDEL region were observed in many of the Sri Lankan cultivars that would be either PD tolerant or moderately tolerant or sensitive indicating that the degree of PD tolerance cannot be directly linked to the presence and absence of the INDEL region. For example, the PD tolerant cultivars like Murungakayan, $\mathrm{H}-4, \mathrm{H}-7, \mathrm{Bg} 403$ and Bg 94-1 contained some loci of the INDEL region complicating the MAB for PD tolerance using Pup1 markers in Sri Lankan rice cultivars. If MAB is done solely based on selecting the Kasalath haplotype, the PD tolerant mechanism/s conferred by the cultivars such as H-4, H-7 and Murungakayan will eventually be lost during $\mathrm{MAB}$ and from developed lines.

It is logical to hypothesise that some of the Sri Lankan cultivars may exhibit PD tolerance in the absence of Kasalath Pupl haplotype. Within Pupl locus, the Sri Lankan cultivars exhibited a very high level of genomic diversity, which is very useful in rice breeding but often complicates the process of MAB lowering its applicability as explained in Collard and Mackill (2008) and Hospital (2009). This sort of genetic diversity within Pup1 QTL was found to be caused by higher transposon and retrotransposon activities operated within this genomic region (Heuer et al., 2009). However, it shows the need of diversely adapted mechanisms for PD tolerance in rice cultivars of different geographic locations. As most of the rice growing soils lack available $\mathrm{P}$ in the soil and diverse nature of the soil chemistry and biology worldwide, this adaptive evolution or unintentional selection by our ancestral farmers would have contributed to this much of higher diversity in Pupl genomic region.

\section{Association between the marker alleles and PD tolerance traits}

Out of the 18 polymorphic marker alleles detected, 15 alleles showed significant effects on the traits of PD tolerance $(p<0.05)$. Table 4 exhibits the mean trait value difference when the allele is present and absent in the studied cultivars. Overall the presence of $433 \mathrm{bp}$ band of K46-K2 marker conferred higher PD tolerance. Conversely, when 130 bp allele in K46-CG2 is absent, higher PD tolerance was observed. The gain of selection must be higher when considering the means of allelic states for MAB and Table 4 clearly displays the specific alleles to look for when conducting MAB for PD tolerance. The haplotype or allelic state based breeding is the core practice in molecular breeding and recently coined as 'DNA informed breeding' (Iezzoni et al., 2010; Yunbi, 2010). The allelic states and the haplotypes established in the present study could be used to conduct $\mathrm{MAB}$ of rice for $\mathrm{PD}$ tolerance.

\section{CONCLUSION}

The haplotype analysis of 30 Sri Lankan rice cultivars using 17 DNA markers for Pupl QTL revealed 27 unique haplotypes excluding Kasalath type. The PD tolerant rice cultivars Sudubalawee, Bw 364, Kaluheenati and Marss share the same haplotype which is also present in the standard PD tolerant cultivar, Kasalath. Other PD tolerant SL cultivars contain haplotypes that are more similar to Pupl haplotype of Nipponbare, the standard PD sensitive cultivar, than to that of Kasalath indicating the presence of novel PD tolerant mechanism/s and QTLs within the SL rice germplasm. The association analysis between marker alleles and the traits of PD tolerance shows that a higher gain of selection is possible through selecting the favourable alleles of the associated markers such as 433 bp allele of $K 46-K 2$ marker that favours 0.73 of increased PD tolerance.

\section{Acknowledgement}

This study was funded by the National Research Council (NRC), Sri Lanka (Grant No: NRC 11-087).

\section{Conflict of interest}

Authors declare no conflict of interest on the results reported. 


\section{REFERENCES}

Abuzayed M., El-Dabba N., Frary A. \& Doganlar S. (2016). GDdom: an online tool for calculation of dominant marker gene diversity. Biochemical Genetics 55(2): 155 - 157. DOI: https://doi.org/10.1007/s10528-016-9779-0

Aluwihare Y.C., Dissanayake D.R.R.P., Karannagoda N.N.H., Chamikara M.D.M. \& Sooriyapathirana S.D.S.S. (2016a). Importance of phosphorous to rice plant and marker assisted selection to produce phosphorous deficiency tolerant rice varieties in country specific breeding programmes - a review. Rajarata University Journal 4(1): $5-25$.

Aluwihare Y.C., Ishan M., Chamikara M.D.M., Weebadde C.K., Sirisena D.N., Samarasinghe W.L.G. \& Sooriyapathirana S.D.S.S. (2016b). Characterization and selection of phosphorus deficiency tolerant rice genotypes in Sri Lanka for utilization as parents in breeding programs. Rice Science 23(4): $184-195$.

DOI: https://doi.org/10.1016/j.rsci.2015.10.001

Aluwihare Y.C., Chamikara M.D.M., Dissanayake D.R.R.P., Dissanayake M.D.M.I.M., Karannagoda N.N.H., Dayananda A.G.M.L.K., Sirisena D.N., Samarasinghe W.L.G., Rajapakse R.G.S.C. \& Sooriyapathirana S.D.S.S. (2017). DNA sequence polymorphism of Pupl linked K20-1 STS region can be effectively used in molecular breeding of rice for phosphorus deficiency tolerance. Journal of the National Science Foundation of Sri Lanka 45(4): $413-425$.

DOI: https://doi.org/10.4038/jnsfsr.v45i4.8235

Bennett E.M., Carpenter S.R. \& Caraco N.F. (2001). Human impact on erodable phosphorus and eutrophication: a global perspective. BioScience 51(3): 227 - 234.

Beuzen N.D., Stear M.J. \& Chang K.C. (2000). Molecular markers and their use in animal breeding. The Veterinary Journal 160(1): $42-52$.

DOI: https://doi.org/10.1053/tvj1.2000.0468

Bieleski R. (1973). Phosphate pools, phosphate transport, and phosphate availability. Annual Review of Plant Physiology 24: $225-252$.

DOI: https://doi.org/10.1146/annurev.pp.24.060173.001301

Bradbury P.J., Zhang Z., Kroon D.E., Casstevens T.M., Ramdoss Y. \& Buckler E.S. (2007). TASSEL 5: software for association mapping of complex traits in diverse samples. Bioinformatics 23: 2633 - 2635.

DOI: https://doi.org/10.1093/bioinformatics/btm308

Chin J.H., Gamuyao R., Dalid C., Bustamam M., Prasetiyono J., Moeljopawiro S., Wissuwa M. \& Heuer S. (2011). Developing rice with high yield under phosphorus deficiency: Pup1 sequence to application. Plant Physiology 156: $1202-1216$.

DOI: https://doi.org/10.1104/pp.111.175471

Chin J.H., Lu X., Haefele S.M., Gamuyao R., Ismail A., Wissuwa M. \& Heuer S. (2010). Development and application of gene-based markers for the major rice QTL phosphorus uptake 1. Theoretical and Applied Genetics 120(6): 1073 - 1086 .

DOI: https://doi.org/10.1007/s00122-009-1235-7
Collard B.C.Y., Jahufer M.Z.Z., Brouwer J.B. \& Pang E.C.K. (2005). An introduction to markers, quantitative trait loci (QTL) mapping and marker-assisted selection for crop improvement: the basic concepts. Euphytica 142: 169-196. DOI: https://doi.org/10.1007/s10681-005-1681-5

Collard B.C.Y. \& Mackill D.J. (2008). Marker-assisted selection: an approach for precision plant breeding in the twenty-first century. Philosophical Transactions of the Royal Society B: Biological Sciences 363(1491): 557 - 572. DOI: https://doi.org/10.1098/rstb.2007.2170

Cordell D., Drangert J.O. \& White S. (2009). The story of phosphorus: global food security and food for thought. Global Environmental Change 19(2): 292 - 305. DOI: https://doi.org/10.1016/j.gloenvcha.2008.10.009

Felsenstein J. (2005). PHYLIP (Phylogeny Inference Package) version 3.6. Distributed by the author. Department of Genome Sciences, University of Washington, Seattle, USA.

Heuer S. et al. (11 authors) (2009). Comparative sequence analyses of the major quantitative trait locus phosphorus uptake 1 (Pup1) reveal a complex genetic structure. Plant Biotechnology Journal 7(5): 456 - 471.

DOI: https://doi.org/10.1111/j.1467-7652.2009.00415.x

Holford I. \& Mattingly G. (1976). Phosphate adsorption and availability plant of phosphate. Plant and Soil 44: 377-389. DOI: https://doi.org/10.1007/BF00015889

Hollingsworth P.M., Graham S.W. \& Little D.P. (2011). Choosing and using a plant DNA barcode. PLoSONE 6(5): e19254.

DOI: https://doi.org/10.1371/journal.pone.0019254

Hospital F. (2009). Challenges for effective marker-assisted selection in plants. Genetica 136: $303-310$.

DOI: https://doi.org/10.1007/s10709-008-9307-1

Iezzoni A., Weebadde C., Luby J., Chengyan Yue V.E., Fazio G., Main D., Peace C.P., Bassil N.V. \& McFerson J. (2010). Rosbreed: enabling marker-assisted breeding in Rosaceae. Acta Horticulturea 859: 389 - 394.

DOI: https://doi.org/10.17660/ActaHortic.2010.859.47

Mengistu N., Baenziger P.S., Eskridge K.M., Dweikat I., Wegulo S.N., Gill K. \& Mujeeb-Kazi A. (2012). Validation of QTL for grain yield-related traits on wheat chromosome 3A using recombinant inbred chromosome lines. Crop Science 52: $1622-1632$.

DOI: https://doi.org/10.2135/cropsci2011.12.0677

Moose S.P. \& Mumm R.H. (2008). Molecular plant breeding as the foundation for $21^{\text {st }}$ century crop improvement. Plant Physiology 147(3): 969 - 977.

DOI: https://doi.org/10.1104/pp.108.118232

Nei M. \& Kumar S. (2000). Phylogenetic inference: distance methods. Molecular Evolution and Phylogenetics, p 89. Oxford University Press, Oxford, UK.

Ni J.J., Wu P., Senadhira D. \& Huang N. (1998). Mapping QTLs for phosphorus deficiency tolerance in rice (Oryza sativa L.). Theoretical and Applied Genetics 97: 1361 - 1369. DOI: https://doi.org/10.1007/s001220051030

Pariasca-Tanaka J., Chin J.H., Dramé K.N., Dalid C., Heuer S. \& Wissuwa M. (2014). A novel allele of the P-starvation tolerance gene OSPSTOL1 from African rice (Oryza glaberrima Steud) and its distribution in the genus Oryza. 
Theoretical and Applied Genetics 127(6): 1387 - 1398. DOI: https://doi.org/10.1007/s00122-014-2306-y

Rambaut A. (2018). Molecular Evolution, Phylogenetics and Epidemiology. Available at http://tree.bio.ed.ac.uk/ software/figtree, Accessed 03 March 2018.

Reddy K.R., Kadlec R.H., Flaig E. \& Gale P.M. (1999). Phosphorus retention in streams and wetlands: a review. Critical Reviews in Environmental Science and Technology 29(1): 83 - 146 . DOI: https://doi.org/10.1080/10643389991259182

Ribaut J.M. \& Hoisington D. (1998). Marker-assisted selection: new tools and strategies. Trends in Plant Science 3(6): $236-239$.

Roldan-Ruiz I., Dendauw J., Bockstaele E.V., Depicker A. \& Loose M.D. (2000). AFLP markers reveal high polymorphic rates in ryegrasses (Lolium spp.). Molecular Breeding 6: 125 - 134 .

DOI: https://doi.org/10.1023/A:1009680614564

Shen J., Yuan L., Zhang J., Li H., Bai Z., Chen X., Zhang W. \& Zhang F. (2011). Phosphorus dynamics: from soil to plant. Plant Physiology 156: 997 - 1005.

DOI: https://doi.org/10.1104/pp.111.175232

Wissuwa M. \& Ae N. (2001). Further characterization of two QTLs that increase phosphorus uptake of rice (Oryza sativa L.) under phosphorus deficiency. Plant and Soil
237: $275-286$.

DOI: https://doi.org/10.1023/A:1013385620875

Wissuwa M., Wegner J., Ae N. \& Yano M. (2002). Substitution mapping of Pupl: a major QTL increasing phosphorus uptake of rice from a phosphorus-deficient soil. Theoretical and Applied Genetics 105: 890 - 897.

DOI: https://doi.org/10.1007/s00122-002-1051-9

Wissuwa M., Yano M. \& Ae N. (1998). Mapping of QTLs for phosphorus-deficiency tolerance in rice (Oryza sativa L.). Theoretical and Applied Genetics 97: 777 - 783. DOI: https://doi.org/10.1007/s001220050955

Yan L., Li Y.H., Yang C.Y., Ren S.X., Chang R.Z., Zhang M.C. \& Qiu L.J. (2014). Identification and validation of an over-dominant QTL controlling soybean seed weight using populations derived from Glycine max $\times$ Glycine soja. Plant Breeding 133: 632 - 637.

DOI: https://doi.org/10.1111/pbr.12197

Yunbi X. (2010). Molecular Plant Breeding, $1^{\text {st }}$ Edition. Wallingford, UK; Cambridge, MA.

Zhang X., Yuan Y., Wei Z., Guo X., Guo Y., Zhang S., Zhao J., Song X. \& Sun X. (2014). Molecular mapping and validation of a major QTL conferring resistance to a defoliating isolate of verticillium wilt in cotton (Gossypium hirsutum L.). PLoSONE 9(4): e96226.

DOI: https://doi.org/10.1371/journal.pone.0096226 